\title{
SUSCEPTIBILITY OF COMMON BEAN AND SOYBEAN TO WATER STRESS EVALUATED AT THE SITIS PHENOTYPING PLATFORM
}

\author{
SUSCETIBILIDADE DO FEIJÃO-COMUM E DA SOJA À DEFICIÊNCIA HÍDRICA \\ AVALIADA NA PLATAFORMA DE FENOTIPAGEM SITIS
}

\author{
Cleber Morais GUIMARÃES ${ }^{1}$; Luís Fernando STONE² ; Roberto Kazuhiko ZITO3 $^{3}$ \\ 1. Embrapa Arroz e Feijão, Santo Antônio de Goiás, GO, Brasil. cleber.guimaraes@embrapa.br; 2. Embrapa Arroz e Feijão, Santo \\ Antônio de Goiás, GO, Brasil; 3. Embrapa Soja, Santo Antônio de Goiás, GO, Brasil.
}

\begin{abstract}
The great challenge of breeding programs focused on tolerance to water stress is the precise, in large scale, and automated phenotyping. Therefore, the objective of this study was to assess whether the controlled conditions of SITIS Automated Phenotyping Platform and the protocol used are suitable for discriminating cultivars of common bean and soybean for tolerance to this stress. Two experiments were carried out in randomized block design, in a split plot scheme, with four replications. The main plots had five water regimes, applied after flowering: daily replacement of 100 (control), 80, 60, 40, and $20 \%$ of water evapotranspired in control. The subplots consisted of two common bean cultivars (BRS Pontal and BRS Pérola) in the $1^{\text {st }}$ experiment, and two soybean cultivars (MG/BR 46 Conquista and BR$16)$ in the $2^{\text {nd }}$ one. In each species, the first cultivar is more tolerant to water stress, and the second one is more susceptible. It is possible to use the SITIS Platform and the proposed protocol to evaluate common bean and soybean cultivars for tolerance to water stress. The common bean cultivars evaluated were more sensitive to this stress than soybeans. The best water status of cultivars BRS Pontal and MG/BR 46 Conquista under water stress confirmed their greater tolerance.
\end{abstract}

KEYWORDS: Phaseolus vulgaris. Glycine max. Leaf temperature. Evapotranspiration.

\section{INTRODUCTION}

Water deficiency is the environmental factor that affects the crop yield the most. It affects various physiological factors of plants, among them the photosynthesis, the mobilization of carbohydrate, and the symbiotic fixation of atmospheric nitrogen. Decline in nitrogen $(\mathrm{N})$ fixation with the water deficit in the soil also causes reductions in soybean productivity due to inadequate availability of $\mathrm{N}$ for the production of protein, which is critical for the production of grains. With the decrease in the amount of soil water, the $\mathrm{N}_{2}$ fixed by soybean also decreases, even before other physiological processes are compromised. The effect of water deficiency on $\mathrm{N}$ fixation may result in $15-20 \%$ reduction in the productivity of soybean (SINCLAIR et al., 2007). Plant carbon metabolism, protein synthesis, amino acid metabolism, and cell growth are among the most altered processes in soybean nodules under drought stress (GIL-QUINTANA et al., 2013).

The sensitivity of soybean to the effects of water deficiency in the soil has been linked with the transport of $\mathrm{N}$ as ureides from the nodules to the aerial part of plants. Genotypes that carry $\mathrm{N}$ as amides have its $\mathrm{N}$ fixation less affected by the soil water deficiency than those carrying as ureides. In this case, the great challenge of the soybean breeding is the development of new cultivars with high yield and efficiency of use of $\mathrm{N}$ and water (FENTA et al., 2014).

Adaptation to water deficiency, among other factors, is due to the maintenance of good water status in the plant tissues. Great potential exists for improving drought tolerance in common beans. The Exploitation of this potential will be enhanced by more systematic application of physiological and genomic tools and continued genetic and mechanistic analysis of a range of diverse germplasm, both from within the species and from close relatives. By now, the most important traits appear to be those associated with rooting depth and photosynthate remobilization (BEEBE et al., 2013).

Guimarães et al. (1996), in agreement with previous observations, found that genotypes BAT 477 and Carioca, more tolerant to water deficiency, when subjected to this abiotic stress had higher root density and efficiency in water uptake in the deepest soil layers than the genotype RAB 96, more susceptible to drought. These traits provided lower leaf area reduction and less increase to genotypes Carioca and BAT 477 in the foliar specific weight, which means maintaining the leaf area for carbohydrate synthesis and better flow to the storage sites, which resulted in higher productivity of the genotypes more adapted to drought stress.

In the last decade, the use of phenomic tools for plant phenotyping studies under laboratory and field conditions has attracted the attention of 
researchers. Recently, there has been considerable progress in the development of tools for phenotyping of the aerial part; however, the methods for data processing are still limited (FURBANK; TESTER, 2011; ARAUS; CAIRNS, 2013). In addition, despite intensive efforts in the development of phenomics, the classical methods of manual phenotyping applicable to the field level are still valuable instruments for plant breeding (BEEBE et al., 2013).

To face periods of irregular distribution of rainfall, breeding programs should increase efforts to improve crop genetic gains in water-limited conditions (BEEBE et al., 2013). Progress can be made by selecting productivity for the target environment; however, secondary and constitutive traits related to the productivity gain may even be evaluated under controlled or partially controlled conditions. These traits of recognized value, if combined to increase productivity in drought conditions, can increase the plant breeding process either in parental selection or in the screening of segregating lines (LAFITTE et al., 2003).

A precision phenotyping for drought response is a vital step before implementing the genetic and molecular-physiological strategies to unravel the complex multilayered drought tolerance mechanism and further exploration using molecular breeding approaches for crop improvement (MIR et al., 2012). The accurate phenotyping, with largescale and automated assessment, is the challenge to meet the new demands of breeding programs for drought tolerance. The traits directly related to water deficiency must be evaluated, as stomatal diffusive resistance, leaf water potential, leaf temperature and so one. On the other hand, the remote sensing, such as infrared thermometry, as it is not invasive and provides readings on a large scale, presents high potential of use (GUIMARÃES et al., 2015).

In this sense, a phenotyping platform, named SITIS, was developed at Embrapa Rice \& Beans. It is a real-time automated control system for monitoring plant physiological parameters, soil moisture, greenhouse climate, and irrigation of the soil columns. It is composed of 384 soil columns, packed in PVC pipes with $0.25 \mathrm{~m}$ in diameter and $1.00 \mathrm{~m}$ in height, formed of five rings of $0.20 \mathrm{~m}$ in height, and connected by duct tape, placed on digital scales and with an irrigation point for each column. The amount of water used by the plants can be monitored in each column by the difference in weight.

The objectives of this study were to assess whether the controlled conditions of the SITIS Automated Phenotyping Platform and the protocol used are suitable for discriminating cultivars of common bean and soybean for drought tolerance.

\section{MATERIAL AND METHODS}

The study was performed in a greenhouse, in soil columns, in the SITIS Automated Phenotyping Platform, at Embrapa Rice \& Beans, in the municipality of Santo Antônio de Goiás, GO. The soil used was an Acric Red Latosol (Oxisol).

Two experiments were carried out in a randomized block design, in a split plot scheme, with four replications, each one using 40 soil columns. In the main plots, five water regimes were conducted and, in subplots, two common bean cultivars, in the first experiment, and two soybean cultivars, in the second experiment. The common bean cultivars were BRS Pontal and BRS Pérola and the soybean cultivars were MG/BR 46 Conquista and BR-16. In each species, the first cultivar is considered more tolerant to drought and the second, more susceptible (STOLF-MOREIRA et al., 2011; LANNA et al., 2016). The water regimes consisted of a well-watered treatment throughout the cycle, $\Psi_{\mathrm{m}} \geq-0.035 \mathrm{MPa}$ at $0.10 \mathrm{~m}$ deep, and four drought stress treatments. In these treatments, well-watered condition was maintained until the flowering stages R6 and R2, for the common bean and soybean, respectively, when water restriction was applied by daily replacement of $20 \%, 40 \%, 60 \%$, and $80 \%$ of water evapotranspired at the well-watered treatment (daily replacement of $100 \%$ of water evapotranspired). Evapotranspiration was monitored by the difference of consecutive readings of the columns' weight, measured with digital scales.

Soil columns were packed in PVC pipes with $0.25 \mathrm{~m}$ in diameter and $1.00 \mathrm{~m}$ in height, formed of five rings of $0.2 \mathrm{~m}$ in height, connected by duct tape. Liming and fertilization at sowing were carried out according to the soil chemical analysis and crop requirements in greenhouse conditions, and were made with $15 \mathrm{~g}^{\text {column }}{ }^{-1}$ of lime and $4 \mathrm{~g}$ column ${ }^{-1}$ of the commercial fertilizer 530-15, incorporated into $0.10 \mathrm{~m}$ deep. For common bean, the $\mathrm{N}$ topdressing was performed with $2 \mathrm{~g}$ column $^{-1}$ with ammonium sulfate and applied on the soil surface. Sowing was done with ten seeds column $^{-1}$ and, seven days after emergence, the thinning was made, leaving three plants column ${ }^{-1}$.

We evaluated the grain yield per plant, the number of pods per plant, the number of grains per pod, 100-grain weight and evapotranspiration after R6 and R2 stages, for the common bean and soybean, respectively. The leaf temperature, between 1:00 PM and 2:00 PM, was also evaluated 
on the superior surface of two apical leaves fully expanded and with good solar exposure, with a Fluke 66 infrared thermometer.

Variance and regression analysis were performed by using the SAS software (SAS Institute, 1999). For leaf temperatures, only regression equations were adjusted, since they were evaluated just in two replications.

\section{RESULTS AND DISCUSSION}

Table 1. Summary of the analysis of variance for number of pods per plant, number of grains per pod, 100grain weight, grain yield per plant and cumulative evapotranspiration per soil column (ET).

\begin{tabular}{|c|c|c|c|c|c|c|}
\hline Source of variation & DF & Mean square & & & & \\
\hline & & $\begin{array}{l}\text { Pods per plant } \\
\left(n^{\circ}\right)\end{array}$ & $\begin{array}{l}\text { Grain per pod } \\
\left(n^{\circ}\right)\end{array}$ & $\begin{array}{l}\text { 100-grain } \\
\text { weight (g) }\end{array}$ & Grain yield (g) & ET (L) \\
\hline Common bean & & & & & & \\
\hline Block & 3 & $88.7^{\mathrm{ns}}$ & $0.7^{\mathrm{ns}}$ & $1.0^{\mathrm{ns}}$ & $3.8^{\mathrm{ns}}$ & $230.9^{\mathrm{ns}}$ \\
\hline Water regime $(\mathrm{W})$ & 4 & $174.0 *$ & $1.2 *$ & $76.6^{* *}$ & $829.7 * *$ & $7523.2 * *$ \\
\hline Error a & 12 & 43.9 & 0.2 & 7.0 & 20.6 & 142.2 \\
\hline Cultivar (C) & 1 & $0.9^{\mathrm{ns}}$ & $29.4 * *$ & $464.6 * *$ & $14.0^{\mathrm{ns}}$ & $2586.6 * *$ \\
\hline $\mathrm{W} \times \mathrm{C}$ & 4 & $22.0^{\mathrm{ns}}$ & $0.1^{\mathrm{ns}}$ & $5.1^{\mathrm{ns}}$ & $28.9^{\mathrm{ns}}$ & $54.4^{\mathrm{ns}}$ \\
\hline Error b & 15 & 41.0 & 0.2 & 6.6 & 12.6 & 33.5 \\
\hline $\mathrm{CV}(\%)$ & & 36.4 & 12.5 & 9.0 & 17.3 & 7.4 \\
\hline Soybean & & & & & & \\
\hline Block & 3 & $111.3^{\mathrm{ns}}$ & $0.1^{\mathrm{ns}}$ & $1.9^{\mathrm{ns}}$ & $22.9^{\text {ns }}$ & $158.6^{\mathrm{ns}}$ \\
\hline Water regime $(\mathrm{W})$ & 4 & $1662.7 * *$ & $0.1^{\mathrm{ns}}$ & $10.0^{\mathrm{ns}}$ & $292.0 * *$ & $4387.8 * *$ \\
\hline Error a & 12 & 130.0 & 0.1 & 3.4 & 16.1 & 143.7 \\
\hline Cultivar (C) & 1 & $156.0^{\mathrm{ns}}$ & $0.4 * *$ & $14.7 * *$ & $24.8^{\mathrm{ns}}$ & $1130.8 * *$ \\
\hline $\mathrm{W} \times \mathrm{C}$ & 4 & $41.5^{\mathrm{ns}}$ & $0.1^{\mathrm{ns}}$ & $23.1 * *$ & $8.1^{\mathrm{ns}}$ & $6.1^{\mathrm{ns}}$ \\
\hline Error b & 15 & 124.5 & 0.1 & 2.1 & 11.2 & 48.7 \\
\hline $\mathrm{CV}(\%)$ & & 22.5 & 6.7 & 7.8 & 17.7 & 11.0 \\
\hline
\end{tabular}

The average productivity of the cultivars BRS Pérola and BRS Pontal was $20.5 \mathrm{~g}$ per plant, and the average number of pods per plant was 17.6. The cultivar BRS Pontal presented higher number of grains per pod, 4.6 grains, than 'BRS Pérola', 2.9 grains. On the other hand, the cultivar BRS Pérola showed larger grains, because its 100-grain weight was $32.0 \mathrm{~g}$, while the one of 'BRS Pontal' weighed $25.2 \mathrm{~g}$.

The average productivity of the cultivars MG/BR 46 Conquista and BR-16 was 18.9 g per plant and the average number of pods per plant was 49.7. The cultivar MG/BR 46 Conquista showed higher number of grains per pod, 2.2 grains, than 'BR-16', 2.0 grains. As noted for the common bean, internal compensation occurred in the plant regarding the allocation of carbohydrate in the
Water regimes significantly affected all agronomic components of common bean and the number of pods per plant and grain yield of soybean (Table 1). The cultivars of both species only differed in relation to the number of grains per pod and 100-grain weight, which can be attributed to the genetic characteristics of each cultivar. The interaction between the sources of variation was not significant for any of the variables analyzed in the case of common bean. For soybean, this interaction was significant only for the 100-grain weight. 


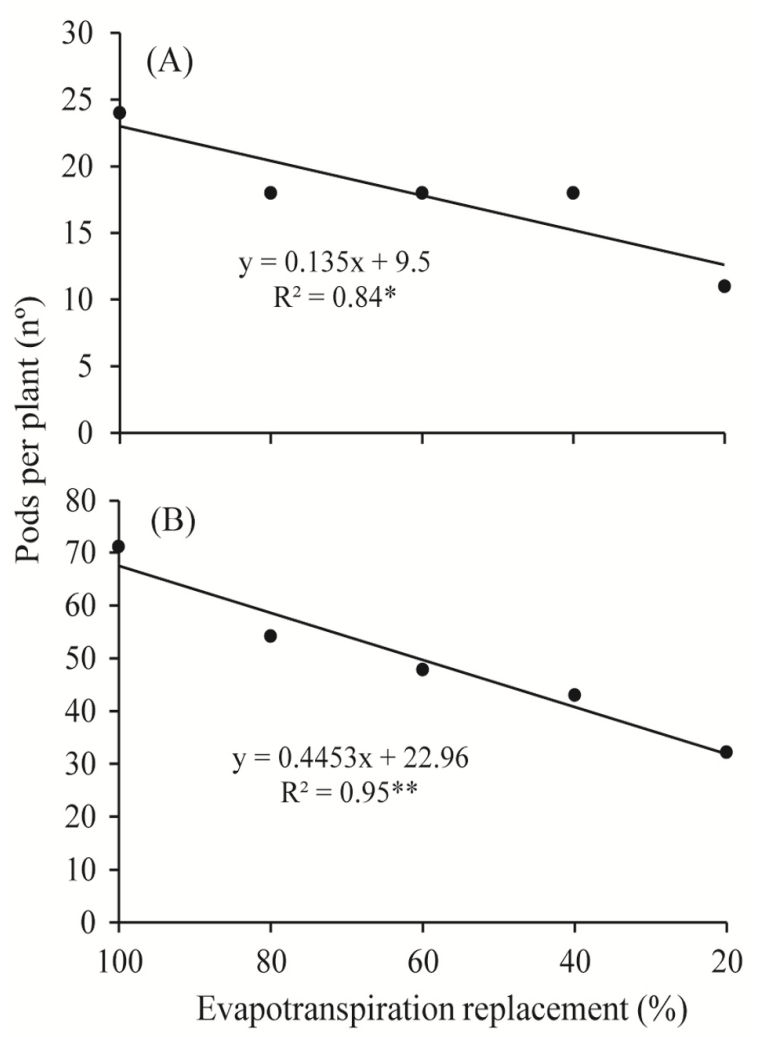

Figure 1. Average number of pods per plant of common bean (A) and soybean (B) cultivars as function of the percentage of evapotranspiration replacement.

The reduction in the number of pods per plant with water stress increase was due to the abscission of flowers and pods in the initial stage of its development, since the treatments are started in the phenological stage R6, in common bean, and R2, in soybean. Sousa and Lima (2010), in common bean, and Manavalan et al. (2009), in soybean, reported abortion of flowers and young pods because of water deficiency.

We observed that the reduction in the number of pods per plant was higher in soybean, equation with greater angular coefficient (Figure 1B), than in common bean (Figure 1A).

The average number of grains per pod of common bean cultivars decreased linearly with the increase of water deficiency (Figure 2A). The average values estimated were 4.1, 3.9, 3.7, 3.5, and 3.3 grains per pod with the replacement of 100,80 , 60,40 , and $20 \%$ of the evapotranspiration, respectively. The different intensities of water deficiency cause differentiated viabilities of pollen grains and, consequently, in the number of grains in the pods. In soybean, this yield component was not affected by water regimes (Table 1), suggesting that the viability of the pollen grains in this crop is less affected by water deficiency than in common bean.

Guimarães et al. (2011) reported that the number of pods per plant was more affected than the number of grains per pod, inferring that the water deficiency acts with more intensity on the abscission of flowers and pods of common bean than on the sterility of the pollen grain, which determines fewer grains per pod.

The 100-grain weight of common bean also decreased linearly with the increasing intensity of water deficiency (Figure 2B). The average values estimated were $32.4 ; 30.5 ; 28.6 ; 26.6$, and 24.7 g per 100 grain with the replacement of $100,80,60,40$, and $20 \%$ of the evapotranspiration, respectively. Muñoz-Perea et al. (2006), evaluating 16 common bean genotypes under water deficiency, observed reduction in the grain weight up to $22 \%$, value compatible with $23.8 \%$ reduction in grain weight with $20 \%$ of evapotranspiration replacement compared with $100 \%$ of replacement.

As previously reported, the interaction between water treatments and soybean cultivars was significant for 100-grain weight; however, it was not possible to adjust significant equations to the data (Figure 3). 

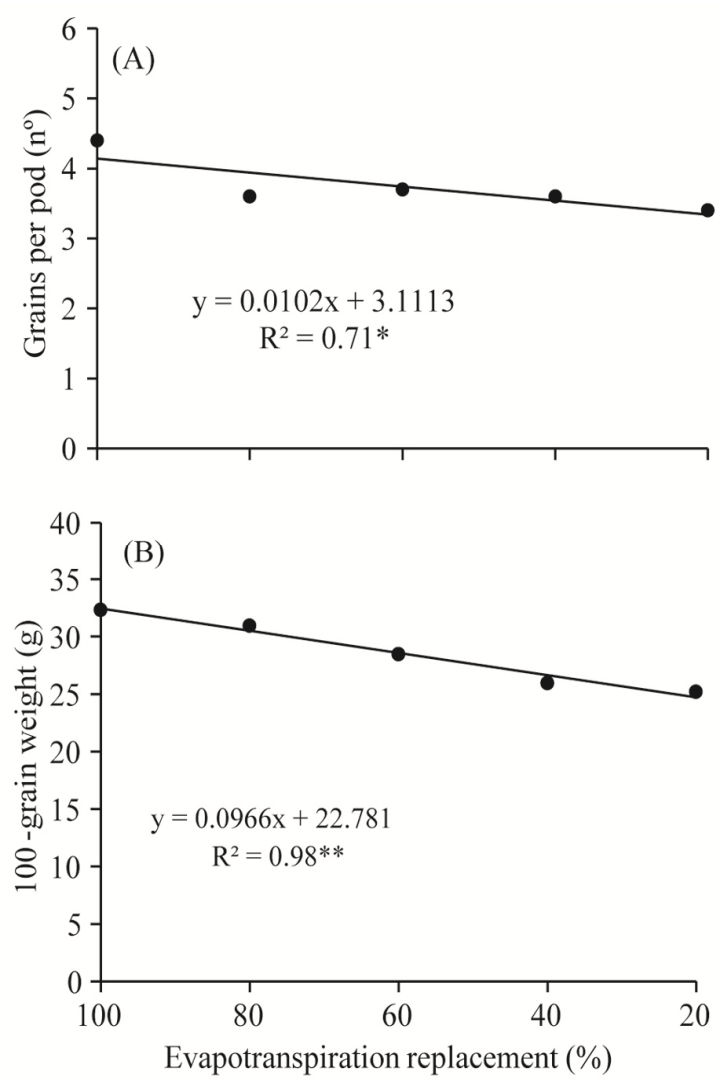

Figure 2. Number of grains per pod (A) and 100-grain weight (B) of common bean cultivars as function of the percentage of evapotranspiration replacement.

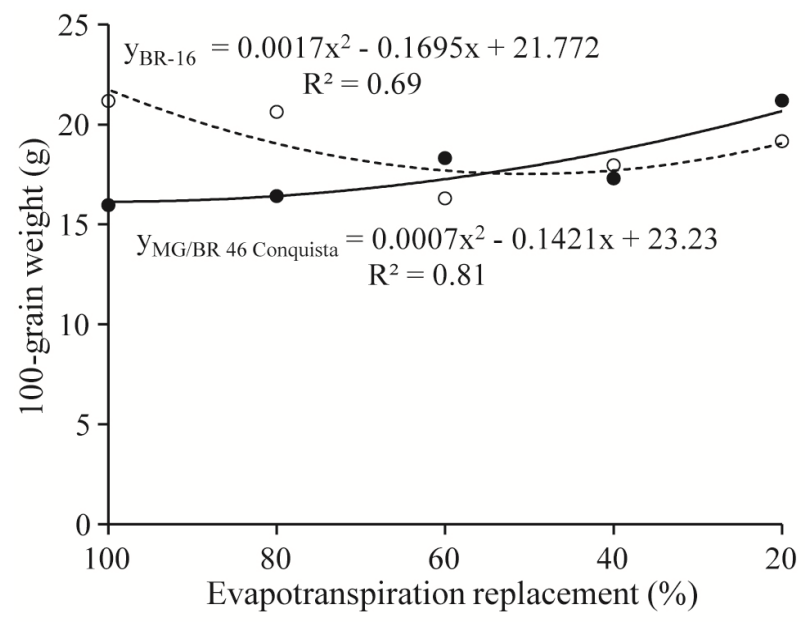

Figure 3. 100-grain weight of soybean cultivars BR-16 and MG/BR 46 Conquista as function of the percentage of the evapotranspiration replacement.

The cultivar MG/BR 46 Conquista, which is more drought tolerant, tended to increase the 100grain weight as the stress increased. The cultivar BR-16, in turn, more susceptible to drought, tended to reduce the 100-grain weight up to $60 \%$ evapotranspiration replacement, but after that, there was little variation. It often occurs compensation among the yield components in soybean, with increase or decrease in seed size according to the number of pods (NOGUEIRA et al., 2012). Apparently, the cultivar MG / BR 46 Conquista 
could exercise more efficiently such compensation under drought.

The reduction in grain weight is result of lower availability of carbohydrates for formation of the grains, due to the lower photosynthetic activity, which is reduced by the drought, and due to the lower translocation of carbohydrates from the synthesis sites to storage sites, in this case, the grain in formation (MANAVALAN et al., 2009).
As a consequence of the effect of water deficiency on the yield components, the average productivity per plant of common bean and soybean decreased with the increase in this stress, according to a quadratic mathematical model in common bean (Figure 4A), and a linear one in soybean (Figure 4B).

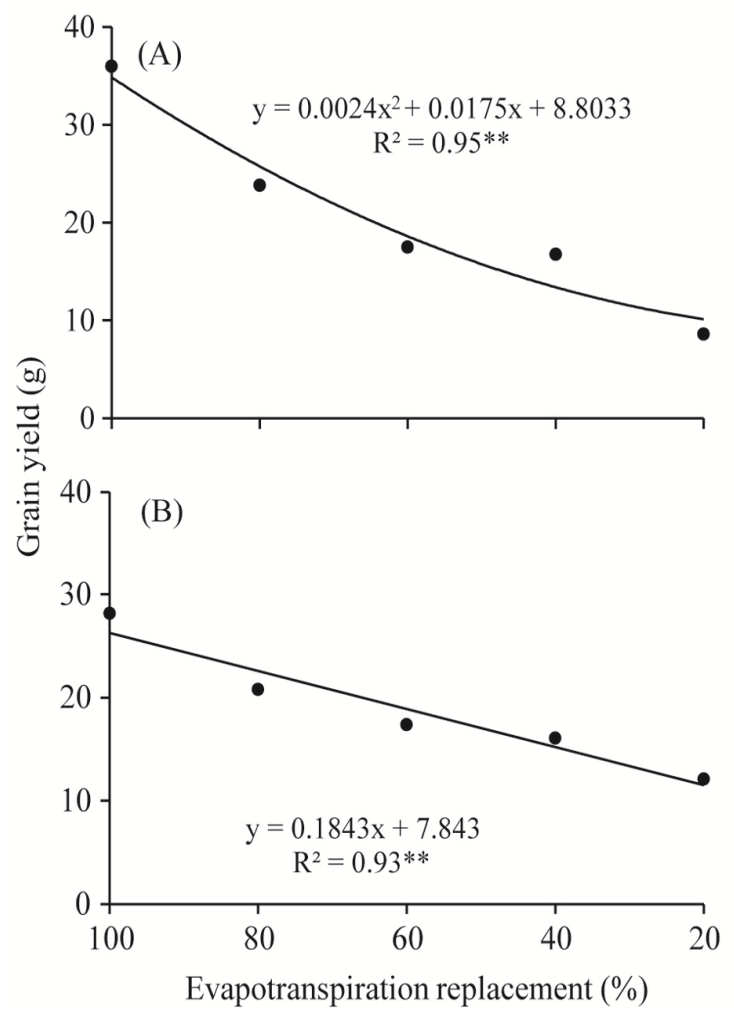

Figure 4. Average grain yield per plant of common bean (A) and soybean (B) cultivars as function of the percentage of the evapotranspiration replacement.

The common bean cultivars yielded, on average, $34.6 ; 25.6 ; 18.5 ; 13.3$, and $10.1 \mathrm{~g}$ per plant with the replacement of $100,80,60,40$, and $20 \%$ of the evapotranspiration, respectively. For the same replacement percentages, average grain yields of the two soybean cultivars were $26.3 ; 22.6 ; 18.9 ; 15.2$, and $11.5 \mathrm{~g}$ per plant.

The reduction of grain yield with the increase in drought was greater for common bean (Figure 5), which suggests that this crop shows greater susceptibility to drought than soybean, which agrees with Vivian et al. (2015).

The water potential of the leaves can be inferred by its temperature (GUIMARÃES et al., 2015), since it increases linearly with the reduction in leaf water potential. In addition, the temperature of the leaves will be higher with the decrease in the transpiration. When the water passes from liquid to gaseous, it removes heat from the environment, thus induces its cooling. In this study, we observed that the temperature of the common bean leaves increased linearly with water deficiency (Figure 6A). The cultivars presented different temperatures, $32.2 ; 34.4 ; 36.6 ; 38,9$, and $41.1^{\circ} \mathrm{C}$, for 'BRS Pérola', and $30.5 ; 32.3 ; 34.2 ; 36.0$, and $37.8^{\circ} \mathrm{C}$, for 'BRS Pontal', with the replacement of $100,80,60$, 40 , and $20 \%$ of the evapotranspiration, respectively.

The cultivar BRS Pontal showed lower leaf temperatures than BRS Pérola in all water regimes, during the period of the day of 1:00-2:00 PM, with intense solar radiation. Additionally, the difference in temperature between the two genotypes increased with increasing water deficiency. We observed temperature differences of $1.6 ; 2.1 ; 2.5 ; 2.9$, and $3.3^{\circ} \mathrm{C}$ with the replacement of $100,80,60,40$, and $20 \%$ of the evapotranspiration, respectively. Data 
suggest that, even when they are not submitted to drought, the cultivars present differences in temperature, probably because they differ in transpiration.

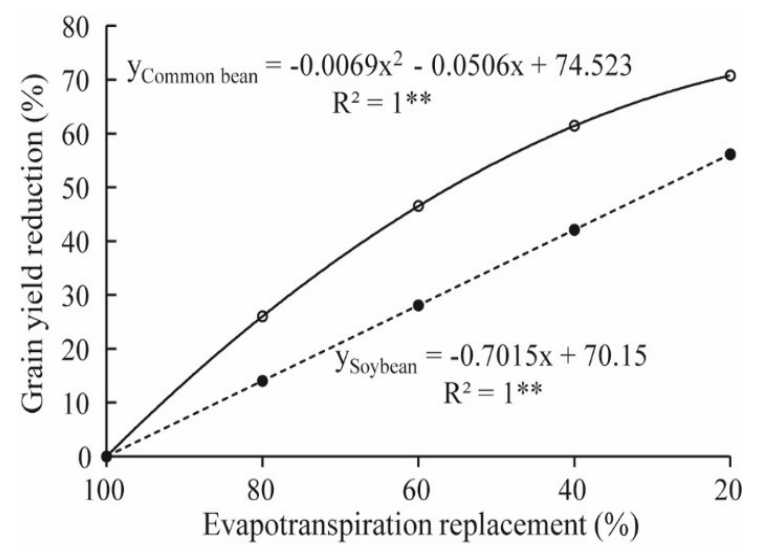

Figure 5. Grain yield reduction of common bean and soybean cultivars as function of the percentage of the evapotranspiration replacement.

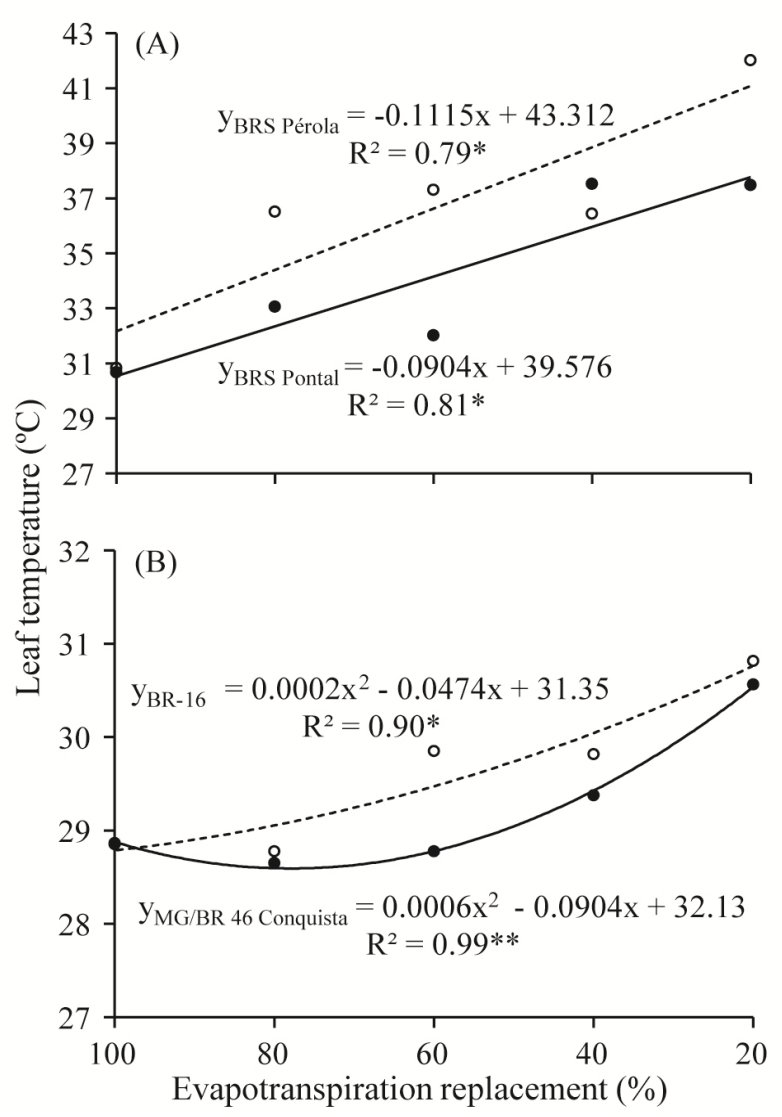

Figure 6. Leaf temperature of common bean (A) and soybean (B) cultivars as function of the percentage of the evapotranspiration replacement.

Guimarães et al. (2011) verified that the productivity of various genotypes of common bean under water deficiency decreased with increasing leaf temperature. The genotypes that showed lower leaf temperatures also had a better production because of their better water status. We also observed that both the number of grains per pod and the number of pods per plant were reduced with increasing leaf temperature.

The leaf temperature of soybean, in turn, showed a quadratic response to the evapotranspiration replacement, with differentiated behavior between cultivars (Figure 6B). Under wellirrigated conditions, the leaf temperatures of the two 
cultivars were similar, probably because the plants also presented similar transpiration. With the application of water deficiency, there was an increase in leaf temperature, and the cultivar BR-16, more susceptible to this stress, presented continuous increasing in its leaf temperature with the stress intensification. The cultivar MG/BR 46 Conquista, more tolerant to water deficiency, maintained similar leaf temperatures up to $60 \%$ of evapotranspiration replacement, when the process of increasing leaf temperature with water deficiency began. Stolf-Moreira et al. (2011) also verified that the leaf temperature of these two cultivars increased as the water deficiency increased, however they did not observe differences regarding this physiologic parameter.

The cumulative evapotranspiration of common bean and soybean from the flowering stages decreased linearly with water deficiency (Figures 7A and 7B). Muñoz-Perea et al. (2007) also found that the evapotranspiration of the common bean is reduced under water deficiency.
The common bean cultivars differed regarding the cumulative evapotranspiration (Table 1), with the cultivar Pérola, more drought susceptible, showing higher average value, $86.5 \mathrm{~L}$ per column, than the cultivar BRS Pontal, more drought tolerant, that evapotranspired $70.5 \mathrm{~L}$ per column. Lanna et al. (2016) found that the cultivar BRS Pérola, under water deficiency, transpired more than the genotype BAT 477 , tolerant to this stress. They also verified, under these conditions, that the root system of 'BAT 477' was, on average, about 50\% higher in length, surface area and volume in the $25-45 \mathrm{~cm}$ soil layer in relation to that of 'BRS Pérola'. Additionally, the plants of 'BAT 477' showed significant reduction in osmotic potential and, consequently, osmotic adjustment, which did not occur with the plants of the cultivar BRS Pérola. As a result, with the imposition of water deficiency, most of the yield components of the cultivar BAT 477 showed higher values than those of 'BRS Pérola', resulting in a smaller reduction in the grain yield, $33 \%$ versus $53 \%$, when compared with the irrigated control.

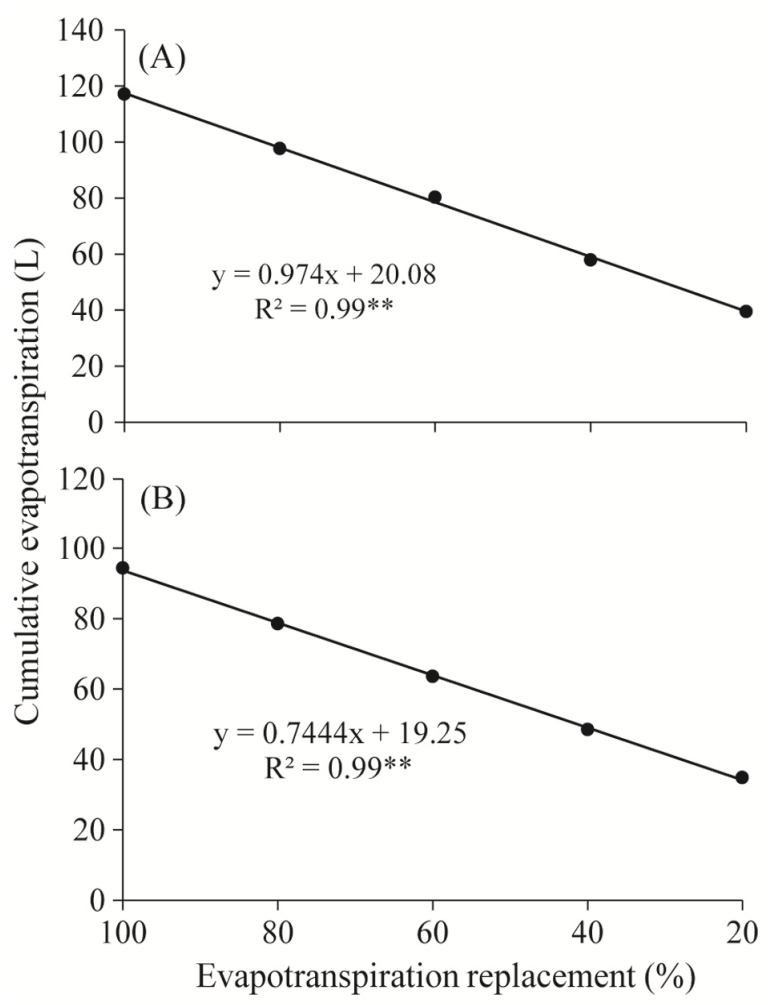

Figure 7. Cumulative evapotranspiration per soil column of common bean (A) and soybean (B) cultivars as function of the percentage of the evapotranspiration replacement.

Unlike observed in common bean, the cultivar MG/BR 46 Conquista, regarded as more tolerant to water deficiency, evapotranspired more than cultivar BR-16, more susceptible. We observed average evapotranspiration of $69.3 \mathrm{~L}_{\text {column }}{ }^{-1}$, by the cultivar MG/BR 46 Conquista, and $58.5 \mathrm{~L}$ column $^{-1}$, by the cultivar BR-16. Under water deficiency, Stolf-Moreira et al. (2011) found lower reduction in photosynthetic rate and stomatal conductance of the cultivar MG/BR 46 Conquista in 
relation to cultivar BR-16, suggesting that the latter cultivar presents partial closure of the stomata under this stress, which could explain its lower evapotranspiration.

\section{CONCLUSIONS}

The SITIS Platform and the proposed protocol can be used to evaluate cultivars of common bean and soybean for tolerance to drought stress.

The common bean cultivars evaluated were more susceptible to drought stress than those of soybean, showing greater grain yield reduction under this stress.

The best water status of cultivars BRS Pontal of common bean and MG/BR 46 Conquista of soybean under water deficiency confirmed their greater tolerance to this stress.

RESUMO: O grande desafio dos programas de melhoramento com foco na tolerância à deficiência hídrica é a fenotipagem precisa, em larga escala e automatizada. Assim, objetivou-se avaliar se as condições controladas da Plataforma Automatizada de Fenotipagem SITIS e o protocolo utilizado são adequados para discriminar cultivares de feijão e soja quanto à tolerância a esse estresse. Foram conduzidos dois experimentos em blocos ao acaso, em parcelas subdivididas, com quatro repetições. Nas parcelas foram conduzidos cinco regimes hídricos, aplicados após a floração: reposição diária de 100 (controle), 80, 60, 40 e 20\% da água evapotranspirada no controle. As subparcelas consistiram de duas cultivares de feijão (BRS Pontal e BRS Pérola), no $1^{\circ}$ experimento, e duas de soja (MG/BR 46 Conquista e BR-16), no $2^{\circ}$. Em cada espécie, a primeira cultivar é mais tolerante à deficiência hídrica e a segunda é mais suscetível. É possível usar a Plataforma SITIS e o protocolo proposto para avaliar cultivares de feijão e soja quanto à tolerância à deficiência hídrica. As cultivares de feijão foram mais sensíveis a esse estresse do que as de soja. O melhor status hídrico das cultivares BRS Pontal e MG/BR 46 Conquista sob deficiência hídrica confirmou sua maior tolerância a esse estresse.

PALAVRAS-CHAVE: Phaseolus vulgaris. Glycine max. Temperatura das folhas. Evapotranspiração.

\section{REFERENCES}

ARAUS, J. L.; CAIRNS, J. E. Field high-throughput phenotyping: the new crop breeding frontier. Trends in Plant Science, Oxford, v. 19, n. 1, p. 1-62, 2013. http://dx.doi.org/10.1016/j.tplants.2013.09.008

BEEBE, S. E.; RAO, I. M.; BLAIR, M. W.; ACOSTA-GALLEGOS, J. A. Phenotyping common beans for adaptation to drought. Frontiers in Physiology, Lausanne, v. 4, n. 35, p. 1-20, 2013. http://dx.doi.org/10.3389/fphys.2013.00035

FENTA, B. A.; BEEBE, S. E.; KUNERT, K. J.; BURRIDGE, J. D.; BARLOW, K. M.; LYNCH, J. P.; FOYER, C. H. Field phenotyping of soybean roots for drought stress tolerance. Agronomy, Basel, v. 4, n. 3, p. 418-435, 2014. http://dx.doi.org/10.3390/agronomy4030418

FURBANK, R. T.; TESTER, M. Phenomics - technologies to relieve the phenotyping bottleneck. Trends in Plant Science, Oxford, v. 16, n. 12, p. 635-644, 2011. http://dx.doi.org/10.1016/j.tplants.2011.09.005

GIL-QUINTANA, E.; LARRAINZAR, E.; SEMINARIO, A.; DÍAZ-LEAL, J. L.; ALAMILLO, J. M.; PINEDA, M.; ARRESE-IGOR, C.; WIENKOOP, S.; GONZÁLEZ, E. M. Local inhibition of nitrogen fixation and nodule metabolism in drought-stressed soybean. Journal of Experimental Botany, Oxford, v. 64, n. 8, p. 2171-2182, 2013. http://dx.doi.org/10.1093/jxb/ert074

GUIMARÃES, C. M.; BRUNINI, O.; STONE, L. F. Adaptação do feijoeiro (Phaseolus vulgaris L.) a seca. I. Densidade e eficiência radicular. Pesquisa Agropecuária Brasileira, Brasília, v. 31, n. 6, p. 393-399, 1996.

GUIMARÃES, C. M.; STONE, L. F.; CASTRO, A. P. de; MORAIS JUNIOR, O. P. Physiological parameters to select upland rice genotypes for tolerance to water deficit. Pesquisa Agropecuária Brasileira, Brasília, v. 50, n. 7, p. 534-540, 2015. http://dx.doi.org/10.1590/S0100-204X2015000700003 
GUIMARÃeS, C. M.; STONE, L. F.; DEL PElOSO, M. J.; OlIVEIRA, J. P. de. Genótipos de feijoeiro comum sob deficiência hídrica. Revista Brasileira de Engenharia Agrícola e Ambiental, Campina Grande, v. 15, n. 7, p. 649-656, 2011. http://dx.doi.org/10.1590/S1415-43662011000700001

LAFITTE, R.; BLUM, A.; ATLIN, G. Using secondary traits to help identify drought-tolerant genotypes. In: FISCHER, K. S.; LAFITTE, R.; FUKAI S.; ATLIN, G.; HARDY, B. (Ed.). Breeding rice for drought-prone environments. Los Baños (Philippines): International Rice Research Institute, 2003. p. 37-48.

LANNA, A. C.; MITSUZONO, S. T.; TERRA, T. G. R.; VIANEllO, R. P.; CARVAlHO, M. A. de F. Physiological characterization of common bean (Phaseolus vulgaris L.) genotypes, water-stress induced with contrasting response towards drought. Australian Journal of Crop Science, Lismore, v. 10, n. 1, p. 1-6, 2016.

MANAVALAN, L. P.; GUTTIKONDA, S. K.; TRAN, L. P.; NGUYEN, H. T. Physiological and molecular approaches to improve drought resistance in soybean. Plant \& Cell Physiology, Kyoto, v. 50, n. 7, p. 12601276, 2009. http://dx.doi.org/10.1093/pcp/pcp082

MIR, R. R.; ZAMAN-ALLAH, M.; SREENIVASULU, N.; TRETHOWAN, R.; VARSHNEY, R. K. Integrated genomics, physiology and breeding approaches for improving drought tolerance in crops. Theoretical and Applied Genetics, Berlin, v. 125, n. 4, p. 625-645, 2012. http://dx.doi.org/10.1007/s00122-012-1904-9

MUÑOZ-PEREA, C. G.; ALLEN, R. G.; WESTERMANN, D. T.; WRIGHT, J. L.; SINGH, S. P. Water use efficiency among dry bean landraces and cultivars in drought-stressed and non-stressed environments. Euphytica, Wageningen, v. 155, n. 3, p. 393-402, 2007. http://dx.doi.org/10.1007/s10681-006-9340-z

MUÑOZ-PEREA, C. G.; TÉRAN, H.; ALLEN, R. G.; WRIGHT, J. L.; WESTERMANN, D. T.; SINGH, S. P. Selection for drought resistance in dry bean landraces and cultivars. Crop Science, Madison, v. 46, n. 5, p. 2111-2120, 2006. http://dx.doi.org/10.2135/cropsci2006.01.0029

NOGUEIRA, A. P. O.; SEDIYAMA, T.; SOUSA, L. B.; HAMAWAKI, O. T.; CRUZ, C. D.; PEREIRA, D. G.; MATSUO, E. Análise de trilha e correlações entre caracteres em soja cultivada em duas épocas de semeadura. Bioscience Journal, Uberlândia, v. 28, n. 6, p. 877-888, 2012.

SAS Institute. Procedure guide for personal computers. Version 5. Cary: SAS Institute Inc., 1999.

SINClAIR, T. R.; PURCELL, L. C.; KING, C. A.; SNELLER, C. H.; CHEN, P.; VADEZ, V. Drought tolerance and yield increase of soybean resulting from improved symbiotic $\mathrm{N}_{2}$ fixation. Field Crops Research, Amsterdam, v. 101, n. 1, p. 68-71, 2007. http://dx.doi.org/10.1016/j.fcr.2006.09.010

SOUSA, M. A. de; LIMA, M. D. B. Influência da supressão da irrigação em estádios de desenvolvimento do feijoeiro cv. Carioca Comum. Bioscience Journal, Uberlândia, v. 26, n. 4, p. 550-557, 2010.

STOLF-MOREIRA, R.; LEMOS, E. G. M.; CARARETO-ALVES, L.; MARCONDES, J.; PEREIRA, S. S.; ROLLA, A. A. P.; PEREIRA, R. M.; NEUMAIER, N.; BINNECK, E.; ABDELNOOR, R. V.; OLIVEIRA, M. C. N. de; MARCELINO, F. C.; FARIAS, J. R. B.; NEPOMUCENO, A. L. Transcriptional profiles of roots of different soybean genotypes subjected to drought stress. Plant Molecular Biology Reporter, Athens, v. 29, n. 1, p. 19-34, 2011. http://dx.doi.org/10.1007/s11105-010-0203-3

VIVIAN, G. A.; ROBAINA, A. D.; PEITER, M. X.; PARIZI, A. R. C.; BARBOZA, F. da S.; SOARES, F. C. Rendimento e rentabilidade das culturas da soja, milho e feijão cultivados sob condições de sequeiro. Semina: Ciências Agrárias, Londrina, v. 36, n. 5, p. 2943-2950, 2015. http://dx.doi.org/10.5433/16790359.2015v36n5p2943 